\title{
Penilaian Kondisi Akustik Di Dalam Ruang Kelas Melalui Program Simulasi Odeon 5.0 (Studi Kasus: SMP Negeri 4 Banda Aceh)
}

\author{
Rosa Mardiana ${ }^{*}$, Bastian Arifin², Izarul Machdar ${ }^{3}$ \\ ${ }^{1}$ Mahasiswa Program Studi Magister Teknik Kimia Program Pascasarjana Universitas Syiah Kuala, \\ Darussalam Banda Aceh, Aceh Indonesia, 2017 \\ ${ }^{2,3}$, Staf Pengajar Jurusan Teknik Kimia, Fakultas Teknik Universitas Syiah Kuala \\ Darussalam Banda Aceh, Aceh Indonesia, 2017 \\ *Koresponden email: rosa_mjh@yahoo.com
}

Masuk: 20 November 2017

Diterima: 11 Desember 2017

\begin{abstract}
School is one of areas that must be controlled by noise level. In accordance with the quality standards of noise level at the school or educational institution is $55 \mathrm{~dB}$. The school conditions polluted air pollution will affect the comfort and ultimately student in learning process and give bad effect for the students' achievement concentration decreases. The aim of the research is to analyze noise level and see composite materials to reduce noise levels through computer simulation approach. Parameter acoustic test in the noisy background (Background of Noise), Sound Pressure Level Distribution, Time buzz, Speech Transmission Index (STI) and Insulation. The sample of this research is in SMPN 4 Banda Aceh. Based on the data obtained, it is found that the noise levels at the site beyond the expiry of the quality standards required that at one point in the school yard around $76.8 \mathrm{~dB}$, point 2 in classrooms around $66.1 \mathrm{~dB}$ and point 3 outside of school grounds around $77.7 \mathrm{~dB}$. Based on simulation results for Clarity / C80 superior to the material to 3, for reverberation time and decay (D50 and T30) superior to the material to 4th and 5th, while for clarity conversation / STI all the ingredients fit in either category.
\end{abstract}

Keywords: School, noise, acoustic parameters, ODEON 5.0 simulation.

Abstrak. Sekolah merupakan salah satu kawasan yang harus dikendalikan tingkat kebisingannya. Baku mutu tingkat kebisingan pada sekolah atau institusi pendidikan adalah $55 \mathrm{~dB}$. Kondisi sekolah yang tercemar polusi udara akan mempengaruhi kenyamanan belajar siswa dan pada akhirnya konsentrasi dan prestasi belajar siswa menurun. Penelitian ini bertujuan untuk menganalisis kondisi tingkat kebisingan terhadap baku mutu kebisingan sekolah yang dipersyaratkan dan melihat bahan material komposit yang dapat mengurangi tingkat kebisingan melalui pendekatan simulasi komputer. Parameter akustik yang di uji adalah bising latar belakang (Backround Noise), Distribusi Tingkat Tekanan Suara, Waktu Dengung, Speech Transmission index (STI) dan Insulasi. Berdasarkan Hasil pengukuran dilokasi SMPN 4 Banda Aceh, menyatakan bahwa tingkat kebisingan di lokasi tersebut melebihi dari batas baku mutu yang dipersyaratkan yaitu pada titik 1 di halaman sekolah sekitar 76,8 $\mathrm{dB}$, titik 2 didalam ruang kelas sekitar $66,1 \mathrm{~dB}$ dan titik 3 di luar halaman sekolah sekitar 77,7 dB. Berdasarkan hasil simulasi untuk Clarity/C80 unggul pada bahan ke 3, untuk waktu dengung dan peluruhannya (D50 dan T30) unggul pada bahan ke 4 dan ke 5, sedangkan untuk kejelasan percakapan/ STI semua bahan masuk dalam kategori baik.

Kata Kunci : Sekolah, Kebisingan, Parameter Akustik, Simulasi ODEON 5.0 


\section{Pendahuluan}

Sebagian besar orang tidak menyadari bahwa suara menyebabkan terganggunya kenyamanan khususnya sistem pendengaran yaitu kehilangan kemampuan pendengaran dan komunikasi yang diakibatkan oleh polusi suara tersebut (Machdar, 2009).

Berbagai macam aktivitas manusia seperti bekerja, bersekolah, berbicara berkendara, dan lain sebagainya selalu akan menghasilkan suara baik berlebihan maupun tidak. Kebisingan seperti yang tercantum dalam Peraturan Pemerintah No. 41, merupakan bagian dari pencemaran udara dan harus dikendalikan dengan menguji baku mutu secara berkala. Sebelumnya pada 25 November 1996, Sarwono Kusumaatmadja (Eks Menteri Negara Lingkungan Hidup) telah menetapkan Keputusan Menteri Negara Lingkungan Hidup tentang Baku Tingkat Kebisingan untuk setiap peruntukkan kawasan atau lingkungan kegiatan seperti perumahan, perdagangan, ruang terbuka, perkantoran, industri, fasilitas umum, tempat rekreasi, rumah sakit, sekolah atau sejenisnya dan tempat ibadah.

Sekolah merupakan salah satu kawasan yang harus dikendalikan tingkat kebisingannya. Baku tingkat kebisingan pada sekolah atau institusi pendidikan adalah 55 dB (KEPMENLH No. 48, 1996) (Hustim, dkk, 2013). Kondisi sekolah yang tercemar polusi udara akan mempengaruhi kenyamanan belajar siswa dan pada akhirnya konsentrasi dan prestasi belajar siswa menurun. Kenyamanan lingkungan sekitar pada saat terjadinya proses belajar mengajar merupakan

\section{Tabel 1. Data Hasil Pengukuran untuk} Bising Latar Belakang

\begin{tabular}{ccccc}
\hline \multirow{2}{*}{$\begin{array}{c}\text { Frekuensi } \\
(\mathrm{Hz})\end{array}$} & \multicolumn{3}{c}{ SPL } \\
\cline { 2 - 5 } & T1 & T2 & T3 & Rata-Rata \\
\hline 63 & 76.8 & 66.1 & 77.7 & 73.53 \\
100 & 63.3 & 64.1 & 64.3 & 63.90 \\
125 & 61.6 & 62.4 & 65.7 & 63.23 \\
250 & 66.7 & 62.9 & 67.4 & 65.67 \\
500 & 69.0 & 58.3 & 71.7 & 66.33 \\
1000 & 68.8 & 55.5 & 66.9 & 63.73 \\
2000 & 62.3 & 58.8 & 57.6 & 59.57 \\
4000 & 55.6 & 62.1 & 48.0 & 55.23 \\
8000 & 44.4 & 44.1 & 39.1 & 42.53 \\
\hline
\end{tabular}

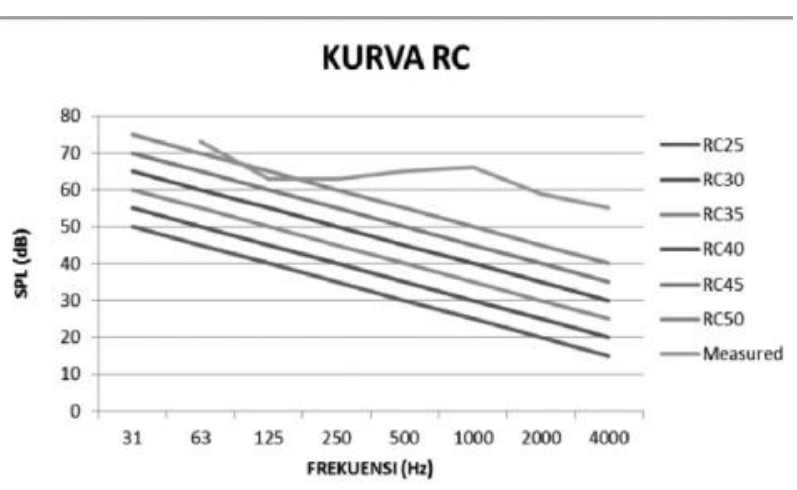

Gambar 1. Kurva RC bising latar belakang pada ruang kelas

faktor penting yang dapat mempengaruhi hasil belajar yang dilakukan oleh individu.

Hampir seluruh lokasi sekolah di Provinsi Aceh, khususnya Kota Banda Aceh berada di tepi jalan raya dan ada yang berdekatan dengan lokasi ber-langsungnya aktifitas pasar. Sebagai objek dalam penelitian ini adalah Sekolah Menengah Pertama Negeri 4 yang berlokasi di Jl. H. T. Daud Syah No. 24 Kel. Peunayong. Sekolah ini berada di tepi jalan raya dan dekat dengan lokasi pasar Peunayong. Pemetaan lokasi tersebut tidak menutup kemungkinan besar bahwa sekolah tersebut mengalami pencemaran udara khususnya kebisingan

Berbagai penelitian-penelitian telah banyak dilakukan untuk mendapatkan material yang mampu mengendalikan kebisingan secara green technology dengan memanfaatkan bahan-bahan dari alam sehingga mampu menekan biaya produksi dan penggunaan unrenewable source (Mediastika, 2008). Material penyerap bunyi mempunyai peranan yang sangat penting dalam akustik ruangan, perancangan studio rekaman, ruang perkantoran, sekolah dan ruang lain untuk mengurangi kebisingan yang pada umumnya sangat menggangu. Material ini disebut material akustik yang berfungsi untuk menyerap dan meredam suara (Thamrin, 2013).

Untuk mencapai kualitas sumber daya manusia dari segi pendidikan pada siswa-siswi Sekolah

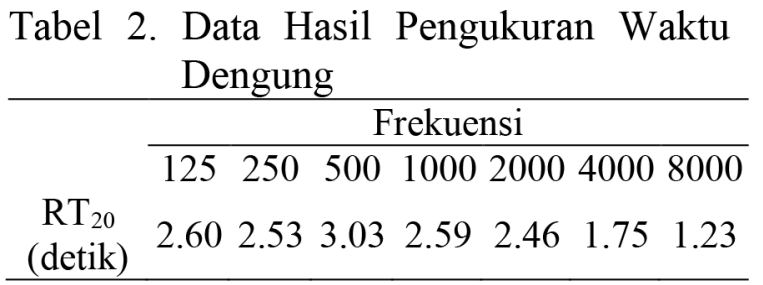




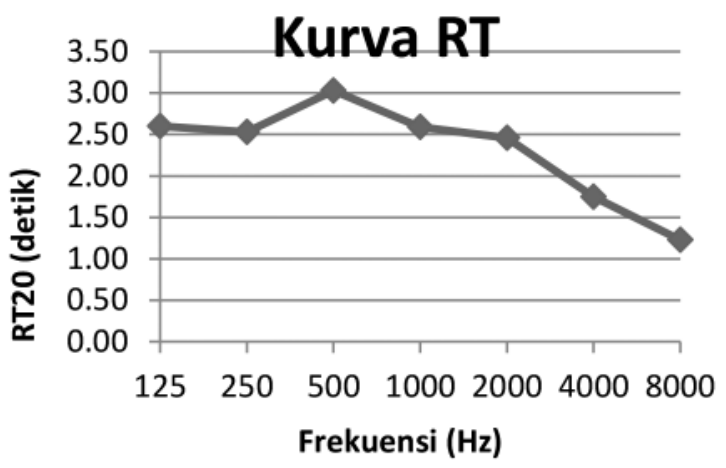

Gambar 2. Kurva waktu dengung

Menengah Pertama Negeri 4 Banda Aceh yang unggul perlu dikaji tingkat kebisingan pada bangunan sekolah tersebut. Kondisi bangunan sekolah yang dikelilingi oleh hiruk pikuk areal transaksi jual beli dan lalu lalang kendaraan memungkinkan sekolah tersebut tercemar kebisingan. Kondisi ini yang mendasari peneliti untuk mengetahui pengaruh kinerja bahan bangunan/beton yang telah dimodifikasi dengan serbuk serat ijuk dan bahan ramah lingkungan lainnya terhadap tingkat kebisingan pada ruangan. Penelitian ini bertujuan untuk mempelajari tingkat penyerapan suara terhadap bising lalu lintas pada ruang kelas di SMP Negeri 4 Banda Aceh. Tujuan khusus yang ingin dicapai adalah untuk:

1. Menganalisis kondisi tingkat kebisingan terhadap nilai baku mutu kebisingan sekolah yang dipersyaratkan

2. Melihat Bahan/Material Komposit (Panel dinding) yang bisa mengurangi tingkat kebisingan

3. Menganalisis tingkat kebisingan di SMP Negeri 4 Banda Aceh dan membuat penilaian kinerja akustik didalam ruangan melalui pendekatan simulasi computer.

Tabel 3 Data Hasil Pengukuran untuk STI

\begin{tabular}{ccccc}
\hline SPL & STI & Kualitas & Cis & LA \\
\hline T1 & 0,53 & Fair & 0,72 & 72,9 \\
T2 & 0,53 & Fair & 0,72 & 73,0 \\
T3 & 0,41 & Poor & 0,62 & 71,5 \\
T4 & 0,41 & Poor & 0,62 & 71,3 \\
T5 & 0,39 & Poor & 0,59 & 71,0 \\
\hline
\end{tabular}

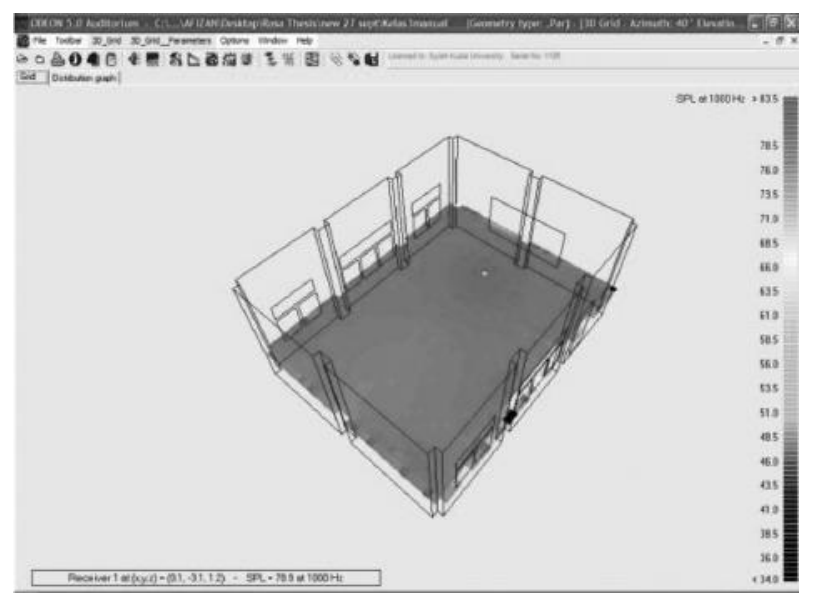

Gambar 3. sebaran untuk distribusi tingkat tekanan suara

\section{Metode Penelitian}

\subsection{Alat dan Bahan}

Untuk Mengukur parameter-parameter akustik, Alat yang akan digunakan pada penelitian ini adalah Precision Sound Analyser NOR140. Perangkat Precision Sound Analyser NOR 140 ini terhubung dengan mikrophon sebagai sensor untuk menangkap bunyi yang akan diukur dari suatu kondisi ruang. Sebelum memulai pengukuran, alat ini di kalibrasikan terlebih dahulu agar data yang didapat lebih akurat.

\subsection{Parameter Akustik yang di uji}

Parameter akustik yang di uji adalah bising latar belakang (Backround Noise), Distribusi Tingkat Tekanan Suara, Waktu Dengung, Speech Transmission index (STI) dan Insulasi.

\subsection{Metode Simulasi Odeon 5.0}

Permodelan yang akan dilakukan dalam penelitian ini, menggunakan perangkat lunak ODEON 5.0 for Auditorium. ODEON merupakan program pemodelan kondisi akustik dan prediksi parameter-parameter akustik ruangan yang menerapkan hybrid Method dalam perhitungan akustik ruangan. Hybrid method ini adalah kombinasi dua metode dasar yang digunakan dalam perhitungan parameter akustik, yaitu: Image Source Method dan ray tracing method. Simulasi akustik dilakukan dalam beberapa tahap yaitu pemodelan geometri ruangan dan penentuan material ruangan, penentuan sumber suara dan posisi titik ukur, mengasumsikan beberapa 


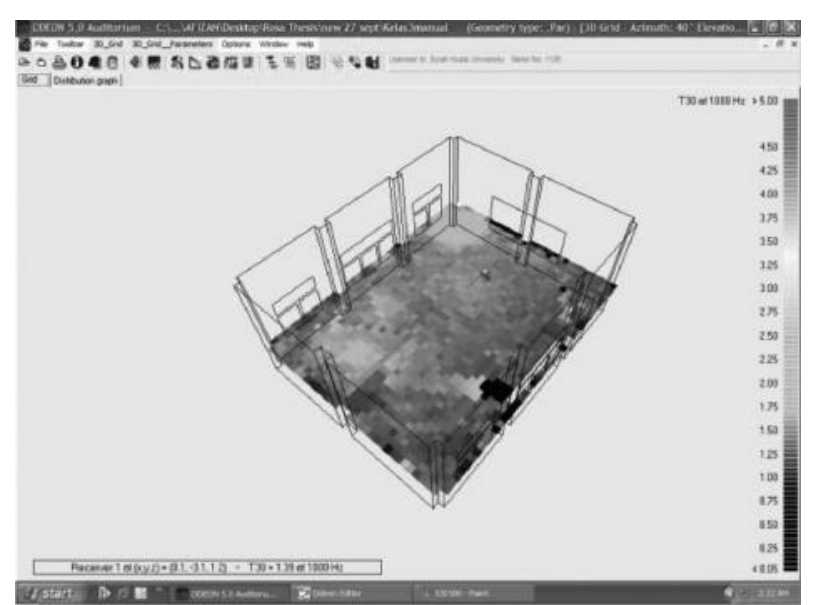

Gambar 4. sebaran untuk waktu dengung (T30)

parameter umum lingkungan akustik dan menjalankan proses kalkulasi.

Pemodelan geometri ruangan dilakukan dengan membagi keseluruhan permukaan didalam ruangan menjadi bidang-bidang datar. Tiap bidang disusun oleh titik sudut yang posisinya dinyatakan dalam koordinat ruang $(\mathrm{x}, \mathrm{y}, \mathrm{z})$ dan dalam ukuran aslinya dalam satuan meter. Titik pusat koordinat terletak di tengah-tengah ruangan. Tiap-tiap titik sudut dan bidang dinyatakan dengan nomor identitas yang unik. Kemudian koefisien absorpsi dan koefisien penghamburan material ruangan frekuensi $125 \mathrm{~Hz}-8 \mathrm{Khz}$ ditentukan dari material library ODEON berdasarkan kondisi bangunan yang sebenarnya (Zulfian, 2004).

\section{Hasil Dan Pembahasan}

\subsection{Parameter Akustik Pada Ruangan Kelas}

Untuk menilai kondisi akustik di dalam ruang kelas secara objektif, perlu diketahui besarnya parameter-parameter akustik ruangan dengan menggunakan metode pengukuran pada saat ruang kelas dalam keadaan kosong dan terisi. Parameter akustik ruang tersebut meliputi Bising Latar Belakang, Distribusi Tekanan Suara, Waktu Dengung, Insulasi dan STI. Pengukuran dilakukan dengan menggunakan Norsonic Analyzer NOR140 dikombinasikan dengan Speaker Omni Power 4296 sebagai sumber suara. Omni Power 4296 Speaker ini diletakkan di depan bagian tengah ruangan dengan ketinggan 1,50 m dari lantai untuk merepresentasikan kondisi orang berbicara dalam keadaan berdiri.

\subsection{Hasil Pengukuran \\ a. Bising Latar Belakang}

Berdasarkan data di Tabel 1, maka untuk mengetahui besarnya bising latar belakang dapat dilihat pada kurva RC di bawah ini.

\section{b. Distribusi Tingkat Tekanan Suara}

Untuk melihat sebaran distribusi tingkat tekanan suara pada ruang kelas. Secara umum, menunjukkan bahwa distribusi tingkat tekanan suara pada ruangan kelas di SMP N 4 Banda Aceh tidak cukup merata disemua titik. Permasalahan ini dikarenakan sumber kebisingan tidak hanya berasal dari dalam ruangan akan tetapi sumber kebisingan tertinggi berasal dari kegiatan diluar ruangan kelas.

\section{c. Waktu Dengung}

Waktu dengung ruangan merupakan suatu parameter karakteristik ruangan yang menggambarkan seberapa baik kondisi ruangan dengan merujuk pada volume dan fungsi ruangan. Untuk ruang kelas, angka waktu dengung yang baik berkisar antara 0.6-0.8 detik. Waktu dengung ruangan didefinisikan sebagai waktu yang dibutuhkan suara dalam suatu ruangan untuk menurunkan kekerasan suara sebesar $60 \mathrm{~dB}$.

Hasil pengukuran waktu dengung dapat digambarkan dalam bentuk grafik yang ditunjukkan pada gambar berikut:

Pada Gambar 2, dapat dijelaskan bahwa pada frekuensi rendah (125 dan $500 \mathrm{~Hz})$ menunjukkan bahwa kurva waktu dengung cenderung naik antara 2,60-3.0 dan pada frekuensi menengah (1000 dan $2000 \mathrm{~Hz})$ menunjukkan bahwa kurva

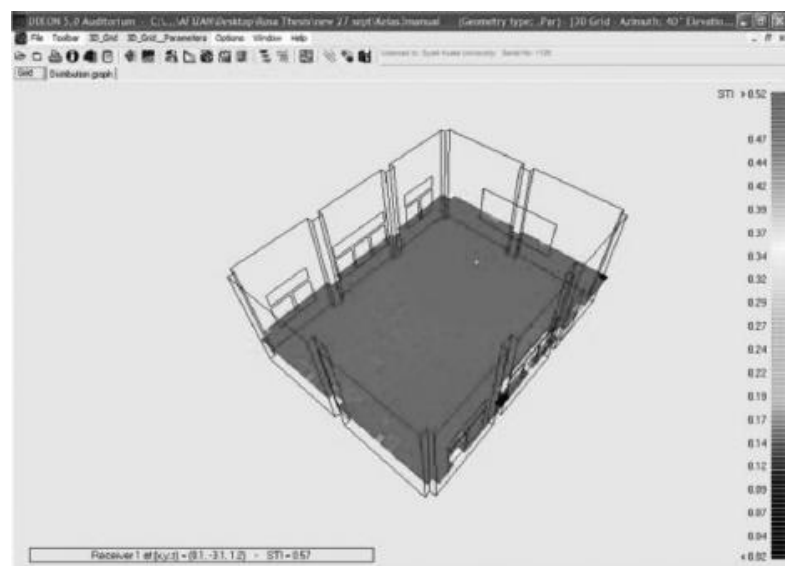

Gambar 5. Sebaran Nilai STI 
waktu dengung mulai menurun dibawah 2,50 dan untuk frekuensi tinggi $(4000$ dan $8000 \mathrm{~Hz})$ mulai menurun lagi hingga batas 1,25 . Hal ini menunjukkan waktu dengung masih cukup tinggi dari batas yang dianjuran.

\section{d. STI}

STI merupakan skala indeks objektif pada frekuensi $125 \mathrm{~Hz}-8 \mathrm{KHz}$ untuk menilai kejelasan percakapan dalam ruangan. Kualitas suara dalam ruangan dapat dinyatakan dengan kondisi nil (0$0.30)$, kurang (0.30-0.45), cukup (0.45-0.60), baik (0.60-0.75) dan sangat baik (0.75-1).

Berdasarkan hasil pengukuran dilapangan, didapat hasil yang tertera didalam Tabel 3 . dibawah ini:

Berdasarkan parameter-parameter akustik yang telah dilakukan pengukuran, maka akan dilakukan simulasikan dengan menggunakan bahan material komposit yang dapat meredam kebisingan, sehingga akan didapatkan ruangan kelas yang sesuai dengan standar baku mutu standar. Komposit yang akan diteliti merupakan material yang banyak ditemukan. Nilai koefisien yang diperoleh dimasukkan kedalam program simulasi ODEON 5.0 untuk mengetahui seberapa besar redaman yang dapat diserap oleh material tersebut.

\subsection{Hasil Sebaran untuk Parameter Akustik Ruangan di Ruang Kelas \\ a. Distribusi Tingkat Tekanan Suara (SPL)}

Berdasarkan hasil simulasi yang ditampilkan pada Gambar 3.3 penampilan distribusi tingkat tekanan suara hasil simulasi memperlihatkan bahwa sebaran cukup merata yaitu berkisar antara 73.5 sampai $78.9 \mathrm{~dB}$.

\section{b. Waktu Dengung (T30)}

Pada Gambar 4 dibawah ini menunjukkan bahwa waktu dengung didalam ruang kelas pada frekuensi 1000 melebihi nilai waktu dengung optimal sebagai ruang percakapan yaitu 1.39 detik. Hal ini menyebabkan kualitas dengung dalam suatu ruangan masih dalam kategori rendah dan tidak bagus.

c. Speech Transmission Index (STI)

Hasil simulasi untuk nilai STI pada frekuensi $1000 \mathrm{~Hz}$ ditampilkan pada Gambar 5 dibawah ini:

Pada gambar 5 menunjukkan sebaran nilai
Speech Transmission Index (STI) di sekitar daerah sumber suara mendekati 0.60 dan daerah tengah serta belakang rentang sebaran berkisar antara 0.47-0.52. Nilai sebaran Speech Transmission Index (STI) secara keseluruh wilayah ruangan kelas masuk kategori cukup, yaitu 0.57

\subsection{Hasil Simulasi dengan Bahan Ramah Lingkungan}

Untuk mengetahui bahan mana yang mampu menyerap suara lebih baik, maka dilakukan pengujian terhadap bahan-bahan yang ramah lingkungan melalui program simulasi ODEON 5.0 for Auditorium.

Bahan material yang dipilih merupakan bahanbahan yang mudah didapat dilingkungan sekitar seperti bahan panel beton busa tanpa serat ijuk, bahan panel beton busa dengan serat ijuk 2\%, bahan panel beton busa dengan serat ijuk 3\%, bahan panel beton busa dengan kelapa sawit dan bahan bambu.

\section{Kesimpulan}

Adapun kesimpulan dari penelitian ini adalah: 1. Tingkat kebisingan dilingkungan sekolah tersebut sudah melebihi dari batas baku mutu yang diisyaratkan untuk sekolah/ institusi pendidikan pada frekuensi 1000 $\mathrm{Hz}$ yaitu pada titik 1 di halaman sekolah $68.8 \mathrm{~dB}$, titik 2 didalam ruang kelas sekitar $55.5 \mathrm{~dB}$ dan titik 3 di luar halaman sekolah sekitar $66.9 \mathrm{~dB}$. Kebisingan yang terjadi berasal dari dalam dan luar lingkungan sekolah.

2. Mengingat bahwa sekolah merupakan salah satu kawasan yang harus dikendalikan tingkat kebisingannya. Maka perlu adanya penambahan bahan material komposit bangunan dari segi akustik untuk ruangan sekolah. Bahan-bahan yang dipilih merupakan bahan berserat yang terdapat dilingkungan sekitar kita dan ramah lingkungan, dan telah diuji nilai koefisiennya. Bahan-bahan yang coba diteliti/disimulasikan ada 5 bahan yaitu: bahan beton busa tanpa serat ijuk, beton busa dengan serat ijuk $2 \%$, beton busa dengan serat ijuk 3\%, beton busa dengan kelapa sawit dan bahan bambu. 
3. Berdasarkan hasil simulasi yang dilakukan melalui program ODEON 5.0 for Auditorium, didapatkan hasil bahwa untuk Clarity/ C80 unggul pada bahan ke 3, untuk waktu dengung dan peluruhannya (D50 dan T30) unggul pada bahan ke 4 dan ke 5, sedangkan untuk kejelasan percakapan/ STI semua bahan masuk dalam kategori baik.

\section{Daftar Pustaka}

Hustim, Muralia. Irmawati, Rita. 2013. Analisa Tingkat Kebisingan Pada Kawasan Sekolah Dasar di Makassar. Universitas Hasanuddin. Makassar.

KepMenLH No. 48 Tahun 1996, tentang Kebisingan dapat Menimbulkan Gangguan Kesehatan Manusia dan Kenyamanan Lingkungan.

Machdar, I., 2009. Question \& Answer : Pengendalian dan Pencemaran. Perdana Mulya Sarana. Medan.

Mediastika, Christina E 2008. Kualitas Akustik Panel Dinding Berbahan Baku Jerami. Universitas Atma Jaya. Yogyakarta. Journal of Architecture and Built Environtment, 127-134

Thamrin, S. 2013. Koefisien Serap Bunyi Papan Partikel dari Bahan Serbuk Kayu Kelapa. FMIPA Unsrat. Manado, Jurnal MIPA UNSRAT, 56-59

Zulfian. 2004. Fisika Bangunan Akustik (Building Acoustic). Laboratorium Akustik. Fakultas Teknik. Universitas Syiah Kuala. Banda Aceh, 24-48. 